\title{
THE NEW INTRUSION TORT: THE NEWS MEDIA EXPOSED?
}

Submitted for the LLB (Honours) Degree

Faculty of Law

Victoria University of Wellington

2013 


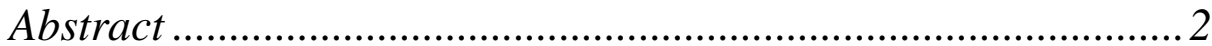

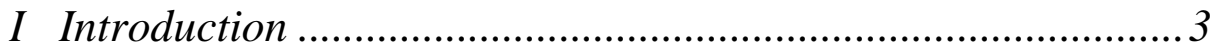

II Policy Justifications for the Intrusion Tort.............................. 4

III How Should the Courts Develop Whata J's Formulation? ....6

A The Formulation ............................................................................................ 7

B Intentional and Unauthorised Intrusion................................................10

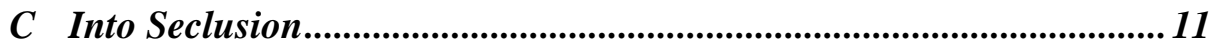

D Reasonable Expectation of Privacy..........................................................16

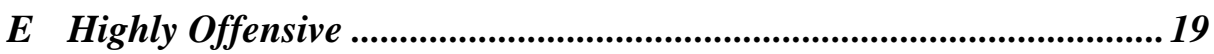

F Legitimate Public Concern .......................................................................22

IV How Should the Intrusion Tort Interact with the Publicity

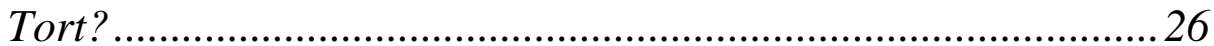

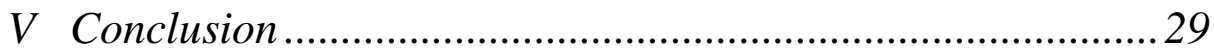

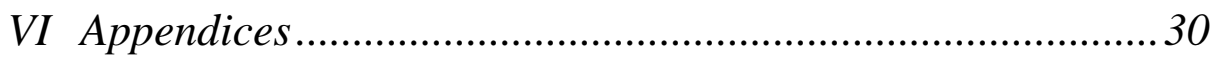

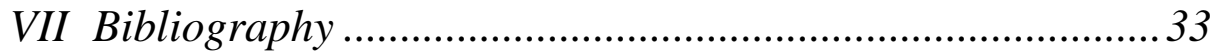

\begin{abstract}
In $C v$ Holland, Whata $\mathrm{J}$ recognised that the tort of intrusion upon seclusion formed part of New Zealand's common law. The tort protects against intentional intrusions into a person's private space. This decision potentially exposes the news media to tortious liability when it engages in intrusive newsgathering practices. However, Whata J's decision provides little guidance as to how the tort should be applied in later cases. In order to ascertain the meaning of the tort's formulation, this essay draws upon the methods used, both in New Zealand and internationally, to prevent the news media from breaching individual privacy rights. It then suggests that the courts should replace the formulation with a one-step reasonable expectation of privacy test. It also argues that the legitimate public concern defence should be better tailored to the intrusion context. Finally, it briefly assesses how the intrusion tort should interact with the tort in Hosking $v$ Runting. Ultimately, it concludes that, in future, the courts should reflect more carefully on the precise wording of the intrusion tort's formulation so that it best vindicates the interests that it was designed to protect.
\end{abstract}

C v Holland - invasion of privacy tort -intrusion upon seclusion newsgathering - news media liability 


\section{Introduction}

C lived in a house with her boyfriend, Z, and Mr Holland. One day, while borrowing Mr Holland's laptop to watch movies, $\mathrm{Z}$ found a video file on the laptop with C's nickname as the title. He tried to access the file, but the link was missing. $\mathrm{Z}$ waited until $\mathrm{Mr}$ Holland had left the house to search $\mathrm{Mr}$ Holland's hard-drive for the file of the same name. $\mathrm{Z}$ discovered that $\mathrm{Mr}$ Holland had installed a video camera in the roof cavity in their bathroom. Mr Holland had been surreptitiously filming $\mathrm{C}$ while she showered. The police charged $\mathrm{Mr}$ Holland for making an intimate visual recording. ${ }^{1} \mathrm{Mr}$ Holland pleaded guilty, was convicted, had to pay $\$ 1000$ in reparation, and was discharged without penalty. ${ }^{2}$

C, still distressed about the filming, brought proceedings against $\mathrm{Mr}$ Holland in tort for invasion of privacy. Previous case law had only permitted a person to succeed in such a claim where there was publication of private facts. Mr Holland had not shown the movie file to anybody else. ${ }^{3}$ The High Court was faced with a unique issue: can a person have an actionable claim in tort for breach of privacy where there is no publication of private facts? In essence, Whata $J$ was required to decide whether the tort of intrusion upon seclusion forms part of the law of New Zealand. He held that it did. ${ }^{4}$

The tort of intrusion upon seclusion provides a cause of action against those who intrude upon a person's private space without publishing any information gathered from the intrusion. Thus, Whata J's decision affects a number of entities, including the news media. Prior to his decision, the news media could only be liable in tort where it published private facts about the plaintiff. Liability risk only became an issue at the point of publication. Following $C v$ Holland (Holland), the news media can be held liable at the point of newsgathering where intrusive methods are used. This might have a chilling effect on newsgathering activities.

This essay will evaluate how the tort of intrusion upon seclusion should develop in order to strike a balance between the protection of individual privacy rights and the news media's ability to freely engage in newsgathering activities. First, it will discuss the policy justifications for the tort. Secondly, it will analyse Whata J's formulation of the tort and suggest

\footnotetext{
${ }^{1}$ Under the Crimes Act 1961, s $216 \mathrm{H}$.

2 The above facts are detailed in C v Holland [2012] NZHC 2155 at [2].

${ }^{3} \mathrm{C} v$ Holland, above $\mathrm{n} 2$, at [2].

${ }^{4} \mathrm{C} v$ Holland, above $\mathrm{n} 2$, at [93].
} 
how the courts should develop it. Thirdly, it will recommend how the intrusion tort should interact with the existing tort of publicity given to private facts. For the purposes of this essay, the news media is defined as an entity whose publishing activities involve a significant element of aggregation of news, information and opinion of current value, which is then disseminated to a public audience on a regular basis. ${ }^{5}$

\section{Policy Justifications for the Intrusion Tort}

The intrusion tort protects against interferences with an individual's private space, as opposed to the publicity tort, which concerns dissemination of private information about a person. Often, the news media will have to interfere with such space in order to gather news. Newsgathering is intimately connected to the publication of stories that are of legitimate interest to the public in a free and democratic society. Tortious liability for such intrusions therefore has the ability to hinder investigative journalism that exposes serious wrongdoing. Any limitation on newsgathering must be justified. This section sets out how the intrusion tort upholds the traditional values that justify legal protection of individual privacy.

The tort protects individual dignity. When someone breaches another person's privacy it affects that latter person's dignity in two ways. First, the former is disregarding the latter's ability to choose which aspects of his or her life are to be kept private, suggesting his or her choices do not merit respect, and consequently undermining his or her sense of self-worth. ${ }^{6}$ Secondly, the former is ignoring the probable effect that his intrusion will have on the latter's emotional wellbeing. ${ }^{7}$ So, when a tabloid publishes private information about an individual, the tabloid is placing its desire to publish above the individual's want for privacy, knowing full well that the individual may suffer emotional distress as a result. ${ }^{8}$ Or, in the context of a

5 This definition is adapted from the definition of the news media provided by the Law Commission in Law Commission The News Media Meets 'New Media': Rights, Responsibilities and Regulation in a Digital Age (NZLC r 128, 2013) at [44].

${ }^{6}$ Nicole Moreham "Why is Privacy Important? Privacy, Dignity and Development of the New Zealand Breach of Privacy Tort” in Jeremy Finn and Stephen Todd (eds) Law, Liberty, Legislation (LexisNexis, 2008) 231 at 236.

${ }^{7}$ Nicole Moreham "Why is Privacy Important? Privacy, Dignity and Development of the New Zealand Breach of Privacy Tort”, above n 6, at 237.

${ }^{8}$ Chris DL Hunt "Conceptualising Privacy and Elucidating its Importance: Foundational Considerations for the Development of Canada’s Fledgling Privacy Tort” (2012) 37 Queen's LJ 167 at 204. 
physical intrusion, when peeping-toms watch these individuals getting undressed, they are is placing their choice to peep above these individuals' desires to get changed in private, while ignoring that the individuals might feel violated as a consequence. ${ }^{9}$ To provide a remedy in tort for the tabloid's actions while not providing one for the peeping-tom's actions would fail to uphold this dignity value.

Privacy advances individual autonomy. Autonomy is the power to make and exercise independent moral judgment, even when such judgment is not a popular one. ${ }^{10}$ Individuals choose how they wish to present themselves to society so as not to solicit the judgment of others. ${ }^{11}$ When individuals retreat from society to their own private space, they are safe to develop their own thoughts and engage in certain behaviours without fear that they will be persecuted for behaving in that way. ${ }^{12}$ Thus, when peepingtoms observe individuals without their knowledge, the peeping-toms are taking away individuals' freedom to decide how they present themselves to society. ${ }^{13}$ Thus, when individuals suspect or find out that somebody is watching them, it stifles their ability to exercise autonomy because they do not feel safe behaving in a way that might attract public scorn. ${ }^{14}$

The advancement of autonomy is necessary in order to safeguard freedom of expression. People do not like being publically judged for their failures. An individual needs to be insulated from ridicule and censure in early stages of experimentation. Thus, if individuals feel that they are under constant surveillance while testing a radical or new idea, they might be too afraid of persecution to engage in learning, creation or questioning. ${ }^{15}$

${ }^{9}$ Chris DL Hunt "Conceptualising Privacy and Elucidating its Importance: Foundational Considerations for the Development of Canada's Fledgling Privacy Tort”, above n 8, at 204.

${ }^{10}$ Ruth Gavison "Privacy and the Limits of Law” (1980) 89(3) Yale Law Journal 421 at 449.

${ }^{11}$ Chris DL Hunt "Conceptualising Privacy and Elucidating its Importance: Foundational Considerations for the Development of Canada's Fledgling Privacy Tort”, above n 8, at 206.

12 Ruth Gavison “Privacy and the Limits of Law” (1980), above n 10, at 448.

13 Chris DL Hunt "Conceptualising Privacy and Elucidating its Importance: Foundational Considerations for the Development of Canada's Fledgling Privacy Tort”, above n 8, at 206.

${ }^{14}$ Chris DL Hunt “Conceptualising Privacy and Elucidating its Importance: Foundational Considerations for the Development of Canada's Fledgling Privacy Tort”, above n 8, at 207.

${ }^{15}$ Ruth Gavison "Privacy and the Limits of Law” (1980), above n 10, at 448. 
Similarly, individuals are less likely to engage freely in communications with others where they think such conversations are being intercepted in an intrusive manner. For example where those individuals' phones are being tapped, or where their conversations are recorded through directional microphones. ${ }^{16}$

Also linked to the autonomy value is the preservation of mental wellbeing. When individuals fail to conduct themselves in accordance with society's behavioural norms, they might be shunned within their communities. ${ }^{17}$ The ability to retreat to a private sphere removes pressure to constantly conform with societal norms, encourages emotional release and ultimately allows the individual to relax. ${ }^{18}$ If this sphere is not protected, and individuals are subject to intrusive surveillance, they might become repressed, alienated, inhibited and suffer from a mental breakdown as a result of not being able to discard the image of themselves that they project publically. ${ }^{19}$

\section{How Should the Courts Develop Whata J's Formulation?}

The previous section detailed the policy justifications for guarding against intrusions upon a person's seclusion. This essay will now discuss how the should courts develop Whata J's formulation of the intrusion tort in Holland.

\footnotetext{
16 Nicole Moreham "Privacy Rights" in Mark Warby QC, Nicole Moreham and Iain Christie (eds) Tugendhat \& Christie's The Law of Privacy and the Media (Second Edition, Oxford University Press, Oxford, 2011) 59 at [2.61]. See also the discussion in the United States Supreme Court case of Bartnicki v Vopper 532 US 514 (2001) at 24 where Rehnquist $\mathrm{J}$, in his dissenting judgment, argued that allowing media defendants to escape liability for illegally intercepting phone conversations would have a chilling effect on the free speech of millions of people who rely on electronic technology to communicate.

${ }^{17}$ Chris DL Hunt "Conceptualising Privacy and Elucidating its Importance: Foundational Considerations for the Development of Canada's Fledgling Privacy Tort”, above n 8, at 210.

18 Chris DL Hunt "Conceptualising Privacy and Elucidating its Importance: Foundational Considerations for the Development of Canada's Fledgling Privacy Tort”, above n 8, at 211.

${ }^{19}$ Ruth Gavison "Privacy and the Limits of Law” (1980), above n 10, at 448.
} 


\section{A The Formulation}

A successful claim under Whata J's formulation requires: ${ }^{20}$

(a) an intentional and unauthorised intrusion;

(b) into seclusion (namely intimate personal activity, space or affairs);

(c) involving an infringement of a reasonable expectation of privacy;

(d) that is highly offensive to a reasonable person.

Whata J suggests that a legitimate public concern in the information might provide a defence to a claim in intrusion. ${ }^{21}$ Presumably "information" refers to the information gathered as a result of the intrusive act.

This formulation was not developed in a vacuum. Whata $\mathrm{J}$ drew upon a number of New Zealand and international sources to inform his test. His starting point was the leading New Zealand Court of Appeal decision on breach of privacy, Hosking $v$ Runting (Hosking). ${ }^{22}$ In this decision, a majority of the Court held that the wrongful publication of private facts was an actionable common law tort if the plaintiff could show: ${ }^{23}$

(1) The existence of facts in respect of which there is a reasonable expectation of privacy; and

(2) Publicity given to those private facts that would be considered highly offensive to an objective reasonable person.

A legitimate public concern in the information is a defence to any claim. ${ }^{24}$ Whata $\mathrm{J}$ considered that the intrusion tort should develop in line with the existing Hosking tort. ${ }^{25}$ The "reasonable expectation of privacy", "highly offensive" and "legitimate public concern" elements of Whata J's formulation are taken directly from the Hosking test.

${ }^{20} \mathrm{C} v$ Holland, above $\mathrm{n} 2$, at [94].

${ }^{21} \mathrm{C} v$ Holland, above $\mathrm{n} 2$, at [96].

${ }^{22}$ In Hosking $v$ Runting [2005] 1 NZLR 1 (CA) the plaintiffs were a celebrity couple who sued a magazine in order to prevent the publication of photos taken of their twin daughters on a busy public street. The plaintiffs were unsuccessful because the photographs published were not "private facts" in which there was a reasonable expectation of privacy.

${ }^{23}$ Hosking v Runting, above $\mathrm{n} 22$, at [117].

${ }^{24}$ Hosking v Runting, above $\mathrm{n} 22$, at [134].

${ }^{25} \mathrm{C} v$ Holland, above $\mathrm{n} 2$, at [96]. 
Whata $\mathrm{J}$ also believed that his formulation should maintain as much consistency as possible with the relevant North American authorities. ${ }^{26}$ In the United States, the Restatement (Second) of Torts (Restatement) divides the right to privacy into four separate torts, ${ }^{27}$ one of which protects against intrusions: ${ }^{28}$

One who intentionally intrudes, physically or otherwise, upon the solitude or seclusion of another or his private affairs or concerns, is subject to liability to the other for invasion of his privacy, if the intrusion would be highly offensive to a reasonable person.

Jones $v$ Tsige (Jones), a recent decision of the Ontario Court of Appeal, incorporated the United States' intrusion tort into the Canadian common law. ${ }^{29}$ Jones summarises the elements of the United States tort as: ${ }^{30}$

(1) An intentional and unauthorised intrusion;

(2) that intrusion was highly offensive to the reasonable person;

(3) the matter intruded on was private; and

(4) the intrusion caused anguish and suffering.

Whata J's formulation adopts all these elements, except for "anguish and suffering" because he considered that element to be more relevant to the assessment of damages. ${ }^{31}$

In addition to the New Zealand and North American common law, Whata $\mathrm{J}$ found support for his new tort in New Zealand legislation that protects against unreasonable intrusions. He did this to show that Parliament accepts that individuals have the right to be free from intrusions into their private space in certain situations. ${ }^{32}$ Although Whata $\mathrm{J}$ did not use these pieces of legislation to develop his formulation, the courts could look to the jurisprudence behind these pieces of legislation to develop the tort in future decisions.

${ }^{26} C$ v Holland, above n 2, at [94].

27 This is discussed at $C v$ Holland, above n 2, at [13]-[14]; See also Restatement (Second) of Torts (1977), §652A. The text of the Restatement can be found at appendix 4.

${ }^{28}$ Restatement (Second) of Torts (1977), §652B.

${ }^{29}$ Jones $v$ Tsige [2012] ONCA 32.

${ }^{30}$ See discussion in $C v$ Holland, above $\mathrm{n} 2$, at [15], referring to Jones $v$ Tsige, above $\mathrm{n} 29$, at [56].

${ }^{31} \mathrm{C} v$ Holland, above $\mathrm{n} 2$, at [18].

${ }^{32} \mathrm{C} v$ Holland, above $\mathrm{n} 2$, at [22]. 
One example of legislative protection against intrusion is found in the Broadcasting Act 1989. This Act gives jurisdiction to the Broadcasting Standards Authority (BSA) to deal with complaints against the broadcast media where the media breaches an individual's privacy. The BSA can award damages where a breach has occurred. ${ }^{33}$ These complaints are judged against the BSA's Privacy Principles. A breach of Privacy Principle $3^{34}$ will occur where the broadcast media publically discloses material obtained through an intentional interference with an individual's interest in seclusion in a way that is highly offensive to an objective reasonable person. ${ }^{35} \mathrm{~A}$ person will generally not have an interest in seclusion when they are in a public place, ${ }^{36}$ but this public place exemption does not apply when the individual is particularly vulnerable and the disclosure is highly offensive to an objective reasonable person. ${ }^{37}$ BSA Privacy Principle $8^{38}$ also provides a public interest defence to defendants akin to that in the Hosking tort where the matter disclosed is of legitimate public concern. ${ }^{39}$

Another example of legislative protection is found in the Privacy Act 1993. Whata J referred to Principle 4(b)(i) of the Act, which prevents an "agency" from colleting information through means that intrude upon an individual's personal affairs to an unreasonable extent. ${ }^{40}$ If information is collected in a way that breaches this principle, a complaint can be brought before the Privacy Commissioner. ${ }^{41}$ Although exemptions to the Privacy Act limit its utility, ${ }^{42}$ the Act is useful to help ascertain the policy

${ }^{33}$ However, the maximum compensation that can be awarded for a successful complaint is $\$ 5,000$. For further information see John Burrows \& Ursula Cheer (eds) Media Law in New Zealand (6 $6^{\text {th }}$ edition, Wellinton, Lexis Nexis, 2010) at 350.

${ }^{34}$ For the text of Privacy Principle 3, see appendix 1.

35 Broadcasting Standards Authority Privacy Principle 3(1).

${ }^{36}$ Broadcasting Standards Authority Privacy Principle 3(2).

${ }^{37}$ Broadcasting Standards Authority Privacy Principle 3(3).

${ }^{38}$ For the text of Privacy Principle 8, see appendix 1.

${ }^{39}$ Broadcasting Standards Authority Privacy Principle 8.

40 Privacy Act 1993, s 6.

41 Privacy Commissioner "Privacy Act \& Codes: Manner of Collection of Personal Information (Principle 4)" <www.privacy.org.nz $>$.

42 The News Media are largely exempt from the Privacy Act 1993 because the definition of "agency" in s 2 excludes any news medium in relation to "news activities". "News activities" include the preparation and public dissemination of programmes concerning news or observations on news, including current affairs and consumer affairs shows and publications. 
considerations that Parliament wishes to advance with respect to the protection of privacy. ${ }^{43}$

One further piece of legislation, to which Whata $\mathrm{J}$ referred, is Part 9A of the Crimes Act 1961. This protects against unauthorised intrusions into personal space. In particular, it is a crime to make an intimate visual recording of another person. ${ }^{44}$

With these sources in mind, this essay will now turn to consider how the courts should develop the individual elements of Whata J's formulation.

\section{B Intentional and Unauthorised Intrusion}

The first question is how should later courts develop the first element of the tort, "intentional and unauthorised intrusion"? This requirement is taken from the summary of the United States' tort in Jones. In Holland Whata J held that Mr Holland intentionally intruded when he videoed C in the shower "without her consent and otherwise without legislative authority."45 In order to develop this element of the tort, the courts will have to clarify what each of its key terms "intentional, "intrusion" and "unauthorised" means.

"Intentional" means an affirmative act, not an accidental or careless act. $^{46}$ Like other intentional torts such as battery, assault and false imprisonment, intention should not require knowledge that the intrusion was wrong; it should merely require intention to commit the act. ${ }^{47}$ Thus, a plaintiff should not be denied a remedy where the defendant mistakenly believes that he or she had lawful authority or the plaintiff's consent to intrude.

It then follows that the term "intrusion" requires the plaintiff to identify a positive act committed by the defendant. Whata J did not explain what kinds of acts are "intrusions". Tugendhat ${ }^{48}$ provides a useful starting point. It identifies recording private conversations, covertly filming people

${ }^{43}$ Hosking v Runting [2003] 3 NZLR 385 at [97].

${ }^{44}$ Crimes Act 1961, s $126 \mathrm{H}$.

${ }^{45} \mathrm{C} v$ Holland, above n 2, at [99].

${ }^{46} \mathrm{C} v$ Holland, above $\mathrm{n} 2$, at [95].

${ }^{47}$ Such a view is also shared, but for different reasons, by Stephen Penk \& Rosemary Tobin “The New Zealand Tort of Invasion of Privacy: Future Directions” (2011) 19 Torts Law Journal 191 at 208.

${ }^{48}$ Mark Warby QC, Nicole Moreham and Iain Christie (eds) Tugendhat \& Christie's The Law of Privacy and the Media (Second Edition, Oxford University Press, Oxford, 2011). 
without their permission, taking photographs with long-lensed cameras, stalking people, pursuing people for interviews and obtaining confidential documents as potentially intrusive acts in the news media context. ${ }^{49}$

"Unauthorised" means that there is no consent to the intrusion or that the intrusion is not authorised by law. ${ }^{50}$ Whata $\mathrm{J}$ did not have to fully consider the meaning of unauthorised in the case because it was clear that $\mathrm{C}$ did not consent to the filming, nor was Mr Holland legally authorised to do so.

Consent is a defence to an intrusive act in the United States tort, ${ }^{51}$ to a charge under s 216G of the Crimes Act, and can mitigate a complaint under principle 4(b)(i) of the Privacy Act. The Crimes and Privacy Acts require informed consent. For the purposes of principle 4(b)(i), if the consent was induced by impersonation it will still amount to an unreasonable intrusion. ${ }^{52}$ Similarly, consent to a charge of making intimate visual recording requires that the person in the recording be of sufficient age and competence to appreciate the nature of the defendant's conduct. ${ }^{53}$ It would be consistent with this jurisprudence to remove the term "unauthorised" from this first element and replace it with the defences of "informed consent" and "lawful authority". This would shift the onus of proof to the defendant, which is desirable because defendants will often be in a better position to point to evidence of consent or the lawful authority if this is what induced them to commit the intrusive act in the first place.

\section{Into Seclusion}

The next element of the formulation is "into seclusion (namely intimate personal activity, space or affairs)". ${ }^{54}$ This element is taken from the Restatement, which reads: "...upon the solitude or seclusion of another or his private affairs or concerns..."55 Whata $\mathrm{J}$ explained that "not every intrusion into a private matter is actionable" 56 and that the "reference to intimate personal activity acknowledges the need to establish intrusion into

\footnotetext{
${ }^{49}$ Nicole Moreham "Privacy Rights”, above n 16, at [2.16].

${ }^{50} \mathrm{C} v$ Holland, above $\mathrm{n} 2$, at [95].

${ }^{51}$ William L Prosser "Privacy” (1960) 48(3) California Law Review 383 at 419.

52 See Case No 14824 [1997] NZPrivCmr 14.

53 Bruce Robertson (ed) Adams on Criminal Law - Offences and Defences (online looseleaf ed, Brookers).

${ }^{54} \mathrm{C} v$ Holland, above $\mathrm{n} 2$, at [94].

${ }^{55}$ Restatement (Second) of Torts (1977), §652B.

${ }^{56} \mathrm{C} v$ Holland, above $\mathrm{n} 2$, at [95].
} 
matters that most directly impinge on personal autonomy”. ${ }^{57}$ He later said: "Mr Holland intruded into C's intimate space and activity when he videoed her in the shower." 58 Little guidance was given as to the scope of the term "seclusion". All that can be ascertained from the case is that a person's private bathroom is an area of "seclusion".

So, what might Whata J mean by "seclusion"? The Restatement provides a useful staring point. It states that the physical intrusion must occur in a place where plaintiffs have "secluded" their person or things. ${ }^{59}$ For example, plaintiffs are secluded when they are in spaces such as their home, or when recovering in a hospital room. ${ }^{60}$ Plaintiffs are not secluded when in public. ${ }^{61}$ Consistent with this, plaintiffs have been denied recovery when the news media filmed a suspect of a crime in the publically accessible hallways of the sheriff's department, ${ }^{62}$ filmed into the interior of a shop from outside the storefront window, ${ }^{63}$ filmed a person walking from his house to his car, ${ }^{64}$ and pursued an interview with a company president in the public space outside the company's building. ${ }^{65}$

However, the fact that someone is in public has not always defeated a plaintiff's claim. For example there was an actionable intrusion in a public space when a member of the press took a photograph of a young woman whose skirt had blown over her head revealing her underwear. ${ }^{66}$ This case shows that the courts will sometimes take a normative approach, rather than a locational approach, when deciding whether an intrusion has occurred. The normative approach looks to the specific circumstances of the case and asks: would fairness and justice dictate that plaintiff ought to succeed?

Whata J's formulation appears to require both a locational and a normative inquiry. His second element asks: is the plaintiff in a state of “seclusion”? ${ }^{67}$ This is a locational inquiry. His third element asks: does the

${ }^{57} \mathrm{C} v$ Holland, above $\mathrm{n} 2$, at [95].

${ }^{58} \mathrm{C} v$ Holland, above $\mathrm{n} 2$, at [99].

${ }^{59}$ Restatement (Second) of Torts (1977), §652B comment (b).

${ }^{60}$ Restatement (Second) of Torts (1977), §652B comment (b).

${ }^{61}$ Restatement (Second) of Torts (1977), §652B comment (c).

${ }^{62}$ Haynik v Zimlich 30 Ohio Misc 2d 16 (1986).

${ }^{63}$ Mark v Seattle Times 96 Wash 2d 473 (1981).

${ }^{64}$ Aisenson v American Broadcasting Company 220 Cal App 3d 146 (Cal 1990).

${ }^{65}$ Machleder v Diaz 538 F Supp 1362 (SDNY, 1982).

${ }^{66}$ Daily Times Democrat v Graham 276 Ala 380 (1964).

${ }^{67} \mathrm{C} v$ Holland, above $\mathrm{n} 2$, at [94]. 
intrusion involve "infringement of a reasonable expectation of privacy"?68 This is a normative inquiry. In developing his formulation, Whata J seems to have been influenced by Shulman $v$ Group W Productions (Shulman), one of the leading United States media intrusion cases. ${ }^{69}$ In this case the Californian Supreme Court set out a two-stage test to work out whether there has been an intrusion upon the seclusion of another. ${ }^{70}$ First, the plaintiff must show that the defendant "penetrated some zone of physical or sensory privacy surrounding, or obtained unwanted access to data about, the plaintiff”, i.e. the locational inquiry. ${ }^{71}$ Second, the plaintiff must have had a "reasonable expectation of seclusion or solitude in the place, conversation or data source”, i.e. the normative inquiry. ${ }^{72}$

But is it desirable to require both a locational and normative inquiry? The locational analysis might provide an additional hurdle for recovery in order to ensure that only deserving plaintiffs who suffer from truly invasive intrusions can recover. Yet this strict locational analysis has attracted much criticism. Although location will always play a part in the analysis as to whether the defendant has breached the plaintiff's privacy, its use as the sole test to determine whether an intrusion has occurred fails to consider other relevant factors that might lead plaintiffs to believe that they have an expectation of privacy. ${ }^{73}$ This essay advocates the removal of the strict locational requirement.

The strict locational requirement fails to uphold the interests that the tort protects. Shulman illustrates the failure of the locational requirement to uphold the dignitary interest of the tort. In that case, the plaintiffs claimed that their right to privacy was intruded upon (1) when the cameraman filmed the accident scene, (2) when accompanied by reporters in the helicopter that

${ }^{68} \mathrm{C} v$ Holland, above $\mathrm{n} 2$, at [94].

${ }^{69}$ In Shulman v Group W Productions 955 P 2d 469 (Cal 1998) the plaintiffs were a mother and a son who had been in a serious car accident. The defendants produced a documentary programme that followed first respondents to emergency scenes. The defendants sent a cameraman along to the scene of the plaintiff's accident to gather footage and audio recordings of the paramedics rescuing the plaintiffs from the accident. The plaintiffs sued for intrusion of privacy.

${ }^{70}$ Shulman v Group W Productions, above n 69, at 490.

${ }^{71}$ Shulman v Group W Productions, above n 69, at 490.

72 Shulman v Group W Productions, above n 69, at 490.

73 See Dr Nicole Moreham "Private Matters: A Review of the Broadcasting Standards Authority" (NZBSA, 2009) at 12-13; and Chris DL Hunt "Privacy in the Common Law: A Critical Appraisal of the Ontario Court of Appeal's Decision in Jones v Tsige” (2012) 37 Queens LJ 665 at 686-688. 
took them to hospital, and (3) when their conversations were recorded through microphones attached to the rescuers. The Court allowed claims (2) and (3) because there was an interest in seclusion in the interior of the helicopter and only unaided ears could hear the conversations. ${ }^{74}$ But the Court rejected the plaintiffs' argument that there was an interest in seclusion in the accident scene itself. ${ }^{75}$ This was because the accident happened on a public road. But it is not the location of the intrusion that determines whether the plaintiffs' dignity has been undermined. Rather, the plaintiffs' dignity was undermined because they were filmed while in a vulnerable state. ${ }^{76}$ The filming turned the plaintiffs' suffering into a spectacle. ${ }^{77}$

Similar criticism can be made in the BSA context. In TVNZ $v$ Davies, TVNZ had filmed the complainant while he was collecting scallops. The complainant was unsuccessful in his intrusion claim because he was publically visible from a little-travelled roadway. ${ }^{78}$ This location-based decision fails to uphold the autonomy and mental health interests that the intrusion tort protects. The complainant might have been collecting shellfish in order to retreat from societal pressures, which would be beneficial for his emotional wellbeing. Also, in finding that the plaintiff's activities were "public" on the basis that he was visible to people generally, the BSA failed to come to grips with the fact that what is "public" is a matter of degree. The complainant was only in "public" in the sense that a small group of people could actually see him. Broadcasting the footage on national television makes the activity "public" on a much larger scale. ${ }^{79}$

An additional argument against the use of a location-based inquiry is that it is notoriously difficult to define "seclusion" based purely on location; to do so would be an oversimplification that could potentially lead to injustice. ${ }^{80}$ Gleeson CJ in $A B C$ v Lenah Meats (quoted in Hosking) reasoned

\footnotetext{
${ }^{74}$ Shulman v Group W Productions, above n 69, at 491.

75 Shulman v Group W Productions, above n 69, at 490.

${ }^{76}$ See discussion in N.A. Moreham "Privacy in Public Places” (2006) NZLJ 265 at 267268.

77 See a critical discussion of the decision in Shulman in Chris DL Hunt "Privacy in the Common Law: A Critical Appraisal of the Ontario Court of Appeal's Decision in Jones $v$ Tsige”, above n 73, at 680 .

${ }^{78}$ Davies v TVNZ [2005] NZBSA 17 at [20].

79 Dr Nicole Moreham "Private Matters: A Review of the Broadcasting Standards Authority”, above n 73, at 11.

${ }^{80}$ Chris DL Hunt "Privacy in the Common Law: A Critical Appraisal of the Ontario Court of Appeal's Decision in Jones v Tsige”, above n 73, at 685.
} 
that while the term "public" is a convenient tool to draw a line between what is private and what is not, the reality is that an activity is not private purely because it does not occur in public. ${ }^{81}$ A locational definition of privacy also fails to recognise that most people understand privacy to be a subjective concept. ${ }^{82}$ For example, one person may believe that her income is an intensely private matter, another may boast about his income to anybody who will listen. ${ }^{83}$

The strict locational requirement is also out of step with current New Zealand law. The "seclusion" element of Whata J's test is similar to the term "private facts" from the first limb of the Hosking tort. When applying the first limb of the Hosking tort, the courts do not engage in two separate inquiries, where (hypothetically) the first would look to whether there are "facts" that are private (in the sense that they are known to only a limited number of people), and second, whether there is a "reasonable expectation of privacy" in those facts. Rather, the courts determine whether "facts" are private by analysing whether there was a "reasonable expectation of privacy" that renders them private. ${ }^{84}$ Tipping J's alternative formulation of the tort in his concurring judgment did not even use the term "private facts". He believed that information becomes "private" either from the nature of the information or the circumstances that the defendant came into the information, not based on how many people are aware of the information. ${ }^{85}$

Furthermore, the Court of Appeal has indicated that the exceptional circumstances of a case may qualify the general rule that a person has no right to privacy in public. ${ }^{86}$ BSA Principle $3(3)$ also recognises that the public place exemption does not apply where the plaintiff is particularly vulnerable. ${ }^{87}$

${ }^{81}$ ABC v Lenah Game Meats [2001] HCA 63; (2001) 185 ALR 1 at [42].

${ }^{82}$ NA Moreham "Privacy in the Common Law: A Doctrinal and Theoretical Analysis" (2005) 121 Law Quarterly Review 628 at 641.

83 This example is taken from NA Moreham "Privacy in the Common Law: A Doctrinal and Theoretical Analysis”, above $\mathrm{n} 82$.

${ }^{84}$ Hosking $v$ Runting, above n 22, at [164]. In Hosking Gault P and Blanchard J held that the photographs of the Hosking twins in New Idea! Magazine did not publicise facts to which there were a reasonable expectation of privacy.

${ }^{85}$ Hosking $v$ Runting, above $\mathrm{n} 22$, at [249].

${ }^{86}$ Hosking $v$ Runting, above $\mathrm{n} 22$, at [164], see also comments made by Anderson $\mathrm{J}$ in the same judgment at [271].

${ }^{87}$ Broadcasting Standards Authority Privacy Principle 3(3). 
Lastly, in the New Zealand experience, the locational inquiry does little analytical work. BSA Principle 3 requires there to be an interference with the plaintiff's interest in "seclusion”. In Canwest, Harrison J defined "seclusion" as a zone of "screening off or shutting off from the outside access or public view." 88 But when determining whether the plaintiff was in a state of seclusion, he asked the normative question: did the plaintiff have a "reasonable expectation of privacy" in that zone? ${ }^{89}$ Subsequent decisions have followed Harrison J's approach. ${ }^{90}$ This approach is undesirable because it creates uncertainty in Principle 3's application by failing to specify how this locational requirement should be dealt with in future cases.

For the above reasons, this essay suggests the strict locational inquiry should be removed from the formulation. Instead, it should be replaced by a single "reasonable expectation of privacy" test that will conduct a normative inquiry into whether plaintiffs "ought" to expect that their activities are private.

\section{Reasonable Expectation of Privacy}

So, if there is to be no strict locational requirement then how should the courts develop the reasonable expectation of privacy element? Whata $\mathrm{J}$ included this element in order to achieve consistency with the existing Hosking tort. ${ }^{91} \mathrm{He}$ concluded that when $\mathrm{Mr}$ Holland videoed $\mathrm{C}$ in the shower it infringed her reasonable expectation of privacy..$^{92}$ Because Whata $\mathrm{J}$ did not discuss this requirement in detail, it is necessary to consider how this requirement works.

This essay suggests that a broad, contextual approach should establish whether a person has a reasonable expectation of privacy. This would be similar to the approach taken by the United Kingdom Court of Appeal in the breach of confidence context. ${ }^{93}$ Relevant considerations

${ }^{88}$ Canwest TVWorks Ltd $v$ XY [2008] NZAR 1 (HC) at [42].

${ }^{89}$ Canwest TVWorks Ltd $v X Y$, above n 88, at [44]-[45].

${ }^{90}$ See, for example, Television New Zealand Ltd $v$ KW HC Auckland CIV-2007-485-1609, 18 December 2008 at [65].

${ }^{91} \mathrm{C} v$ Holland, above $\mathrm{n} 2$, at [96].

${ }^{92} \mathrm{C} v$ Holland, above n 2, at [99].

93 In Murray v Big Pictures Ltd [2008] EWCA Civ 446, [2009] Ch 481 at [36] the English Court of Appeal formulated the following test to establish whether a person had a reasonable expectation of privacy in an action of breach of confidence:

This is an objective test but is a broad one and essentially a question of fact. The Court must take account of all the circumstances of the case. They include the attributes of the claimant, the nature of the activity in which the claimant was 
include: (i) the location of the intrusion, (ii) the purpose for which the plaintiff is in that location, (iii) the nature of the plaintiff's activity, (iv) the method of intrusion, (v) any indication that the plaintiff does not agree to the intrusion, and (vi) the impact on the plaintiff. Each of these considerations will be explained below.

Although this essay has argued that an approach based purely on location is problematic, the location where the intrusion takes place is an important consideration. In the United States, a plaintiff will always have a reasonable expectation of privacy in his or her home, ${ }^{94}$ or in a place with restricted public access, such as his or her workplace. ${ }^{95}$ The BSA has taken a similar approach. A complainant's right of ownership or possession in the location will inform whether there is a reasonable expectation of privacy. ${ }^{96}$ Thus, complainants have a reasonable expectation of privacy when filmed by a hidden camera while opening their front doors, ${ }^{97}$ in the waiting areas of a business that operated inside a house, ${ }^{98}$ when taking photographs of models in their own homes, ${ }^{99}$ when carrying out employment duties inside a house that belongs to someone else, ${ }^{100}$ and on their properties when they are not at home. ${ }^{101}$

Whether the plaintiff is in a public place is not determinative. In Andrews $v$ TVNZ (Andrews) the plaintiffs, who brought their claim under the Hosking tort, were held to have a reasonable expectation of privacy when they were filmed being rescued from their cars following an accident on a public road. ${ }^{102}$ But if the plaintiff is in a public location, it should certainly militate against finding an expectation of privacy.

The consideration of the purpose for which the plaintiff is in the location where the intrusion takes place contemplates whether the plaintiff

engaged, the place at which it was happening, the nature and purpose of the intrusion, the absence of consent and whether it was known or could be inferred, the effect on the claimant and the circumstances in which and the purposes for which the information came to the publisher.

${ }^{94}$ Dietemann v Time Inc 449 F 2d 245 (9th Cir 1971).

95 Sanders v ABC 978 F 2d 67 (Cal 1999).

${ }^{96}$ Canwest TVWorks Ltd v XY, above n 88, at [42].

${ }^{97}$ Television New Zealand Ltd $v$ KW , above n 90, at [62]-[63].

${ }^{98}$ Television New Zealand Ltd $v \mathrm{KW}$, above $\mathrm{n}$ 90, at [64]-[65].

${ }^{99}$ Canwest TVWorks Ltd $v$ XY, above n 88, at [44] \& [48].

${ }^{100}$ CP v TVWorks Ltd [2012] NZBSA 69.

${ }^{101}$ Balfour v TVNZ [2005] NZBSA 129.

${ }^{102}$ Andrews v Televisions New Zealand Ltd [2009] 1 NZLR 220 (HC) at [66]. 
has retreated somewhere to escape from the public gaze. If so, it will point towards a reasonable expectation of privacy.

The nature of the plaintiff's activity should also be borne in mind. If the plaintiff is engaging in an intimate activity, for example toileting or engaging in sexual activity, then this should enhance the plaintiff's expectation of privacy. This approach was adopted in the United States decision in Daily Times Democrat v Graham (mentioned earlier) where the defendant photographed the plaintiff's underwear. ${ }^{103}$

Sometimes the activity is so intimate that the location where the intrusion occurs is irrelevant. Support for this can be found in s 216G(1) of the Crimes Act 1961. Section 216G(1)(a) makes it a crime to make a visual recording of another without his or her knowledge or consent when that person in a place where he or she has a reasonable expectation of privacy, and is either naked, engaging in sexual activity or is showering, toileting or undressing. Section 216G(1)(b) makes it a crime to make a visual recording of a person's intimate body parts from beneath his or her clothing or through his or her outer clothing. In the latter provision, a reasonable expectation of privacy is not a specific requirement. It seems that the circumstances covered by s $216 \mathrm{G}(1)$ (b) are so intimate that it is assumed that a person will have an expectation of privacy.

The same should go where the plaintiff is in a particularly vulnerable situation. BSA Privacy Principle 3 states that, in general, a person does not have an interest in seclusion when in public, ${ }^{104}$ but recognises that this public place exemption does not apply where the complainant is vulnerable. ${ }^{105}$ In $C D \vee$ TV3 Network Services $(C D)$ the complainant was filmed being extracted from her car following an accident, which was broadcast on a comedy show called "Ice As". The broadcast breached Principle 3 because the complainant was traumatised and bleeding from a head wound. ${ }^{106}$

The method of intrusion should be relevant. Where the defendant needs to use a hidden camera, covert recording device, telescopic lens, or other surreptitious means to intrude upon the plaintiff's activity, this will indicate that the plaintiff did not intend for his or her activity to be public, and will consequently point towards a reasonable expectation of privacy.

\footnotetext{
103 Daily Times Democrat v Graham, above n 66.

${ }^{104}$ Broadcasting Standards Authority Privacy Principle 3(2).

105 Broadcasting Standards Authority Privacy Principle 3(3).

${ }^{106}$ CD v TV3 Network Services Ltd [2000] NZBSA 141, 142, 143.
} 
The BSA has held that surreptitious filming with a hidden camera will almost always be an intrusion. ${ }^{107}$

However, where the plaintiffs are aware of cameras, recording devices or the defendant's mere presence and go about their business regardless, this will point against the finding of an expectation of privacy. In the BSA decision in BQ and CR $v$ TVNZ Ltd a couple, who were shown bidding on a house during a reality TV show, were unsuccessful in their intrusion claim because they were aware of the presence of cameras. ${ }^{108}$

Where plaintiffs have made it clear that they want to be left alone, this may enhance the expectation. Another reason why the complainant in $C D$ was successful was because the cameraman continued to film the complainant long after she had requested him to stop. ${ }^{109}$

Lastly, where the defendant acts in a way that is distressing to the plaintiff, then this should aid the finding of a reasonable expectation of privacy. In Hosking, Anderson J believed that if there was an element of embarrassment or distress involved in taking the photographs of the children on the public street then that might have been enough to decide the case differently. ${ }^{110}$ He discussed Peck $v$ United Kingdom, a decision of the European Court of Human Rights, where the plaintiff had a reasonable expectation of privacy in CCTV footage that recorded him attempting to commit suicide. ${ }^{111} \mathrm{~A}$ similar approach was taken in the BSA decision in $C D$ where the complainant was ridiculed during the broadcast for her behaviour following the car-crash. The BSA found that the broadcast reached a point where it became "so offensive and intrusive as to constitute a form of harassment”. ${ }^{112}$

\section{E Highly Offensive}

The final element of Whata J's test is that the intrusion is "highly offensive to a reasonable person”. This is also adopted from Hosking. ${ }^{113}$ This element ensures that defendants are not liable for trivial breaches of privacy. ${ }^{114}$ Only

\footnotetext{
107 See Canwest TVWorks Ltd v XY, above n 88, at [54]; O'Connell v TVWorks Ltd [2007] NZBSA 67 at [68]; and CP v TVWorks Ltd, above n 100. 
distressing breaches are protected. ${ }^{115}$ Whata $\mathrm{J}$ acknowledged that this element of the Hosking test had been subject to criticism, but he believed that the offensiveness element was preferable to a one-step reasonable expectation of privacy test. ${ }^{116}$ He felt that the one-step test was not sufficiently defined. This is a problem because intrusion cases will often involve balancing competing freedoms, thus judges need clear boundaries for intervention. ${ }^{117}$ Whata $\mathrm{J}$ then went on to say that the "highly offensive" test was satisfied in the case without any further explanation. ${ }^{118}$ This essay disagrees with Whata J. It argues that the offensiveness test should be jettisoned because it does little analytical work and fails to protect the plaintiff's dignity.

This element is of little analytical significance because it overlaps with the reasonable expectation of privacy element. Judges have expressed such a view in the context of the publicity tort. In Hosking, Tipping $\mathrm{J}$ felt that offensiveness is generally implicit in any finding that an expectation of privacy is reasonable. ${ }^{119}$ William Young $\mathrm{P}$ in the Court of Appeal decision in TVNZ $v$ Rogers noted that, in most cases, publicity will be highly offensive because it breaches a reasonable expectation of privacy. ${ }^{120}$ Commenting on this qualifier in New Zealand's publicity tort, the New South Wales Law Reform Commission has said that the reasonable expectation of privacy test is enough to bar trivial claims brought by overly sensitive plaintiffs. ${ }^{121}$

The lack of analytical significance is also evident in the BSA complaints process. Privacy Principle 3 requires the BSA to apply an objective test to determine whether an ordinary person would find the intrusion offensive. But in most cases offensiveness follows automatically from a finding of an intrusion upon a space where there is a reasonable expectation of privacy. ${ }^{122}$ Judges often give no reasons why the intrusion is

\footnotetext{
${ }^{115}$ Hosking v Runting, above n 22, at [126].

${ }^{116} \mathrm{C} v$ Holland, above $\mathrm{n} 2$, at [97].

${ }^{117} \mathrm{C} v$ Holland, above $\mathrm{n}$ 2, at [97].

${ }^{118} \mathrm{C} v$ Holland, above n 2, at [99].

${ }^{119}$ Hosking v Runting, above $\mathrm{n} 22$, at [256]-[259].

${ }^{120}$ Television New Zealand v Rogers [2007] 1 NZLR 156 (CA) at [122].

${ }^{121}$ Law Reform Commission Invasion of Privacy (NSWLRC r 120, 2009) at [5.9].

${ }^{122}$ See for example Television New Zealand Ltd $v$ KW, above n 90, at [55] - [61].
} 
highly offensive because the requirement entails a value judgment for which it is difficult to provide clear reasons. ${ }^{123}$

Both of New Zealand's privacy torts have taken the "highly offensive" test from the Restatement. ${ }^{124}$ The best articulation of this element in the United States intrusion context is found in Miller $v$ National Broadcasting Company (Miller), where the Court held that in order to ascertain offensiveness, courts must consider: (1) the degree of the intrusion, (2) the context, (3) the circumstances surrounding the intrusion, (4) the motives and objectives of the intruder, (5) the setting into which he or she intrudes and (6) the expectations of the persons whose privacy is invaded. ${ }^{125}$ Yet the determining factors for "offensiveness" in Miller are almost the exact same considerations found in the reasonable expectation of privacy test that this essay suggests the courts should adopt. Factor (1), the degree of intrusion, will consider the impact of the intrusion on the plaintiff. Factor (2), the context, will examine the nature of the activity the plaintiff is engaged in. Factor (3), the circumstances, will look to the method of the intrusion. Factor (5), the setting, will focus on the location of the intrusion. Factor (6), the expectations of the person whose privacy is invaded, will consider any indications that the person did not want the intrusion to take place and the reason why the plaintiff is at the location.

Therefore, there is no need to include the highly offensive limb to develop the tort in line with the United States jurisprudence because it does the same work as the recommended reasonable expectation of privacy test. The one consideration from Miller that might not be covered by the recommended test is factor (4), the motives and objectives of the intruder. But this consideration is already covered in New Zealand by the "legitimate public concern” defence, which is discussed later.

The danger of including a test that has little analytical significance is that it results in the "offensiveness" element becoming very difficult to apply, which creates unacceptable uncertainty. This is particularly so when Whata J does not give guidance as to how "offensiveness" is to be objectively ascertained. For example, is it offensive from the perspective of

123 Dr Nicole Moreham "Private Matters: A Review of the Broadcasting Standards Authority”, above n 73, at 15.

${ }^{124}$ Restatement (Second) of Torts (1977), §§652B \& 652D.

${ }^{125}$ Miller v National Broadcasting Company 187 Cal App 3d 1463 (Cal 1987) at 679. 
a reasonable person in the plaintiff's shoes? ${ }^{126}$ There is a danger that the resulting uncertainty will deter deserving claimants from bringing complaints or could have an undesirable chilling effect on broadcasters' newsgathering methods.

Another criticism of the highly offensive test is that its application has failed to protect the plaintiff's dignity in the publication tort context. In Andrews, a documentary crew filmed the victims of a car accident. The footage was screened on national television. Allan J declined the plaintiffs' claim on the basis that there was nothing that showed them in a bad light or that was embarrassing. ${ }^{127}$ However, Allan J's reasoning failed to recognise that the highly offensive test exists to ensure relief is given only for breaches that cause real humiliation and distress. Although the plaintiffs were not portrayed in a negative way, they were filmed in a very intimate situation where they were hurt, afraid and vulnerable. This was an affront to their dignity that resulted in real humiliation when the documentary was broadcast. $^{128}$

In Rogers $v$ TVNZ, Elias CJ raised Lord Nicholls criticism of the "highly offensive" test. ${ }^{129}$ He said that it gave an unwarranted weight to an unqualified freedom of expression over the right to privacy. ${ }^{130}$ Thus, by adding an additional hurdle to recovery, the highly offensive test will often fail to protect plaintiffs even when their dignity is severely undermined.

The above criticisms suggest that the "offensiveness" limb should be abandoned.

\section{F Legitimate Public Concern}

After setting out his formulation, Whata $\mathrm{J}$ mentioned that liability could be subject to a defence of legitimate public concern. ${ }^{131}$ He did not explain how this defence works because the facts did not require any consideration of it. This gives rise to questions about how the legitimate public concern defence

\footnotetext{
126 This is how Nicholson $\mathrm{J}$ applied the test in the publicity tort decision in $P$ v $D$ [2000] 2 NZLR 591 (HC).

${ }^{127}$ Andrews v Televisions New Zealand Ltd, above n 102, at [68] - [69].

128 Nicole Moreham "Why is Privacy Important? Privacy, Dignity and Development of the New Zealand Breach of Privacy Tort”, above n 6, at 242-243.

${ }^{129}$ Rogers v Television New Zealand Ltd [2007] NZSC 91, [2008] 2 NZLR 277 at [36].

${ }^{130}$ Campbell v Mirror Group Newspapers Ltd, above n 114, at [134].

${ }^{131} \mathrm{C} v$ Holland, above $\mathrm{n}$ 2, at [96].
} 
will be applied. The Hosking tort, BSA decisions and United States case law can provide some answers.

The legitimate public concern defence is taken from the Hosking tort. Gault P and Blanchard J were concerned that the scope of the privacy tort might limit freedom of expression beyond that which is justified in a free and democratic society. ${ }^{132}$ It is necessary to distinguish matters that are of legitimate concern to the public from those which are merely interesting to the public on a human level. ${ }^{133}$ Where there is a legitimate public concern in the information publicised, this will be balanced proportionally against the harm likely to be caused by the breach of privacy. ${ }^{134}$ The more serious the likely harm caused, the less likely that the defendant's right to freedom of expression will prevail. ${ }^{135}$

A similar defence is enshrined in Privacy Principle 8, which allows a media defendant to breach a privacy principle where the breach discloses a matter of legitimate concern to the public. The BSA employs the same balancing test as in Hosking. It has recognised criminal matters, issues relating to public health and safety, matters of politics, government or public administration, matters relating to the conduct of organisations which impact on the public, exposing misleading claims made by individuals or organisations and exposing antisocial and harmful conduct as all being of public concern. ${ }^{136}$ The defence is also not available to reporters who go on fishing expeditions with the hope of finding illegal or unprofessional conduct when there is no prior evidence that such conduct is occurring. ${ }^{137}$

In general, the BSA has held that broadcasting footage taken from a hidden camera must be justified by exceptional circumstances because the recording of such footage will usually involve a substantive intrusion. ${ }^{138}$

${ }^{132}$ Hosking v Runting, above $\mathrm{n} 22$, at [130].

133 TV3 Network Services Ltd v The Broadcasting Standards Authority [1995] 2 NZLR 720

at 733 cited in Hosking $v$ Runting, above n 22, at [133].

${ }^{134}$ Hosking v Runting, above $n$ 22, at [134].

${ }^{135}$ Hosking v Runting, above n 22, at [134].

${ }^{136}$ Canwest TVWorks Ltd $v X Y$, above n 88, at [58].

${ }^{137}$ In O'Connell $v$ TVWorks Ltd, above n 107, the television show Target set up hidden cameras in a house and got an actress to portray an elderly woman in need of home support. It then hired caregivers a series of caregivers and covertly filmed them going about their jobs. This was not in the public interest because there was no indication that the caregivers were going to behave illegally or unprofessionally.

${ }^{138}$ Canwest TVWorks Ltd $v$ XY, above n 88, at [54]; O’Connell v TVWorks Ltd, above n 107, at [68]; CP v TVWorks Ltd, above n 100. 
Thus, in TV3 Network Services $v$ Fahey (Fahey) the court held that in the circumstances of the case, the obtaining of a surreptitious film was an understandable pre-emptive cause of action. ${ }^{139}$ The Fahey case concerned the granting of an injunction to stop the broadcast of footage obtained surreptitiously in order to expose that a well-known medical professional who was standing for the Christchurch mayoralty had engaged in sexual misconduct with his patients. The decision does not support any general proposition that the ends of newsgathering justify the means. ${ }^{140}$

Care needs to be taken when drawing on the Hosking and BSA material because in all these decisions the courts and the Authority have had the information in front of them from which they can ascertain whether the legitimate public concern in the information trumps the likely harm caused. With intrusion, proceedings might be brought against a journalist well before publication of the information, and there is even a risk that information uncovered from the intrusion may not even turn out to be publishable. This makes it more difficult for the court to determine whether there was legitimate public concern that justified the intrusion.

The United States approach to this issue has been to deny the existence of a public concern defence, but in some cases to consider newsgathering at the highly offensive stage. In Dietemann $v$ Time, Inc (Dietemann), ${ }^{141}$ the Court rejected the defendant's argument that it was immunized from liability under the first amendment of the Constitution ${ }^{142}$ (which protects freedom of the press) because it was using the concealed recording tools for newsgathering. The Court found that newsgathering predates the invention of miniature cameras and recording devices, and

${ }^{139}$ TV3 Network Services Ltd v Fahey [1999] 2 NZLR 129 at 135.

${ }^{140}$ TV3 Network Services Ltd v Fahey, above n 139, at 136.

${ }^{141}$ In Dietemann $v$ Time Inc, above n 94, the defendants were investigating "quack doctors" who were practicing medicine illegally. Dietemann was one of these doctors. An undercover investigator for Life Magazine pretended to be a patient and attended an appointment with the Dietemann with a hidden audio recording device that transmitted the conversations between them to a police car parked outside Dietemann's home. These conversations ousted Dietemann as a fraud. He brought a cause of action against the magazine's owner for intrusion upon seclusion.

142 The First Amendment to the United States Constitution prohibits the making of any law respecting an establishment of religion, impeding the free exercise of religion, abridging the freedom of speech, infringing on the freedom of the press, interfering with the right to peaceably assemble or prohibiting the petitioning for a governmental redress of grievances. 
those devices are not "indispensible tools" of newsgathering. ${ }^{143}$ The Court in Shulman, relying on Dietemann, rejected the defendants' argument that a newsgathering defence should be available against a claim for intrusion where the information is about a matter of legitimate concern to the public and the underlying conduct of gathering the information is lawful. It reasoned that freedom of expression would not be curtailed by refusing the media a general licence to intrude upon another's privacy on the off chance that it finds something worth publishing. ${ }^{144}$ Instead, the Court held that the discovery of socially important information might stop an intrusion from being highly offensive. ${ }^{145}$

This essay suggests that the New Zealand courts should not adopt the United States approach of considering newsworthiness at the highly offensive stage because the highly offensive test is not necessary nor useful. Rather, it advocates following Whata J's suggestion that there be a defence of legitimate public concern, but suggests that the defence needs to be better tailored to the intrusion context.

So how should this be done? This essay recommends that this defence be available where the intrusion took place for the pursuit of information that is of considerable public concern. This would also require that the information be obtained honestly through the use of the least intrusive means possible.

The defence should be pitched at a higher standard than in the Hosking tort because media defendants should have to point to seriously legitimate reasons that justify intrusive newsgathering. The stronger requirement of "considerable" (as opposed to "legitimate") recognises that intrusion proceedings will often be invoked in situations where media defendants have intruded but have not found anything newsworthy. This appropriately balances the need to vindicate privacy rights against the need to safeguard deserving investigative reporting. Matters of considerable public concern would include situations where there is significant danger to health or safety, the detection and prevention of serious crime, exposure of matters that are of financial significance to the general public, and exposure of matters that could have a significant effect on government or public administration. For example, the intrusive investigation in Fahey would

\footnotetext{
143 Dietemann $v$ Time Inc, above n 94, at 249.

144 Shulman v Group W Productions, above n 69, at 496-497.

145 This approach taken in Shulman $v$ Group $W$ Productions was reaffirmed in the Californian Supreme Court's decision in Sanders v ABC, above n 95.
} 
reach this threshold because it had a significant effect on public administration. The investigation had the potential to, and indeed did, show that the mayoral candidate had committed sexual improprieties during his medical career.

The "honesty" requirement ensures that information is obtained in a way that does not involve exploitation of a person's vulnerabilities, coercion or other forms of improper pressure. This protects the dignity interest. Thus, the defence would not have been available to the defendants in Shulman because they took "calculated advantage of the plaintiffs' vulnerability and confusion" when recording the plaintiffs' conversations at the accident scene and when filming inside the ambulance. ${ }^{146}$

The "least intrusive means" requirement limits the defence's availability to situations where intrusion is the only means through which the information can be obtained. In certain circumstances it will be necessary to make an audio or visual recording in order to prove that an activity of considerable public concern is occurring. This would cover situations like in Fahey where the surreptitious filming of the conversation between Dr Fahey and X, who made the allegations of sexual misconduct, was needed to protect X from Dr Fahey's attacks on the credibility of her allegations, especially after he had said, under oath, that she was mentally disordered. ${ }^{147}$

\section{How Should the Intrusion Tort Interact with the Publicity Tort?}

So far, this essay has suggested that Whata J's formulation should develop to require an intentional intrusion that involves an infringement of a reasonable expectation of privacy in an activity, space or affairs, subject to a defence of considerable public concern, consent or lawful authorization. But, this leaves open an important question about how the intrusion tort should interact with the publicity tort. All that Whata $\mathrm{J}$ said about the relationship between the two torts is that they should remain consistent. ${ }^{148}$ Both the publication and intrusion torts require an invasion of a private sphere belonging to the plaintiff. ${ }^{149}$ The fundamental difference between

\footnotetext{
146 Shulman v Group W Productions, above n 69, at 494.

147 TV3 Network Services v Fahey, above n 139, at 135.

${ }^{148} \mathrm{C} v$ Holland, above n 2, at [94] \& [96].

${ }^{149}$ William L Prosser “Privacy”, above n 51, at 407.
} 
them is that the intrusion tort does not require publication. It is therefore likely that plaintiffs will plead causes of action in both torts. This section will briefly consider how the courts might wish to develop the relationship between these two torts.

The United States jurisprudence is useful because both torts have existed there for a number of years. ${ }^{150}$ Keith $\mathrm{J}$ in Hosking described the development of the publicity tort in the United States as: "that ridiculous mouse born of all that mountainous labour." 151 This is because the "legitimate public concern" (or "newsworthiness") defence to the publicity tort allows news media defendants to escape liability in almost all cases because freedom of the press is heavily protected under the Constitution. ${ }^{152}$ When a plaintiff pleads both intrusion and publication of private facts in relation to the same string of acts, he or she may be successful in one tort, but unsuccessful in the other. This was evident in Shulman where the Court (at summary judgment) held that the plaintiffs had an arguable case in intrusion, but also threw out the publication tort claim because to allow a court to find the defendants liable would "assert impermissible supervisory powers over the press.”"153

Yet it seems illogical that a court could be prepared to compensate a person for harm caused by an intrusion, but then would deny recovery for the harm caused by the subsequent publication of any material gathered from that same intrusion. This is unfair on plaintiffs because the courts fail to acknowledge that the news media's actions cause harm beyond the intrusion itself. Publication of private information has a humiliating effect on plaintiffs on a very public level, and failure to provide redress would undermine the dignitary interest of the tort. It is also unfair on the news media. While the courts acknowledge that the news media has a constitutional right to publish a story, this right comes at the price of damages for liability in tort. This is morally undesirable because the news media is paying for its freedom of expression, a constitutionally guaranteed right. This also rewards media defendants who are large enough to afford the litigation risk that comes with publishing private information because

\footnotetext{
150 The Restatement (Second) of the Law of Torts, §652D identifies the elements of the publication of private facts tort action, the text of which can be found at appendix 4 .

${ }^{151}$ Hosking v Runting, above $\mathrm{n} 22$, at [216].

${ }^{152}$ Lyrissa Barnett Lidsky "Prying, Spying and Lying: Intrusive Newsgathering and What the Law Should Do About It” (1999) 73 Tulane Law Review 173 at 199-200.

${ }^{153}$ Shulman v Group W Productions, above n 69, at 497.
} 
smaller media entities that cannot afford the litigation risk are locked out from publishing such information.

Some have suggested that the creation of a compendious tort, which would cover both intrusions and publicity given to private facts, could solve the problems resulting from the inconsistency between the two torts in application. ${ }^{154}$ Other commentators have suggested that the formulation of a single tort would be unmanageable given the different interests that the intrusion tort and the publicity tort vindicate. ${ }^{155}$

This essay advocates striking a middle ground between the United States approach and the formulation of a compendious tort. Both torts should be maintained, but plaintiffs should be precluded from pleading the intrusion tort where there has been publication of private facts gathered as a result of an intrusion. Instead, the plaintiff's only cause of action should be the Hosking tort. This would not result in a failure to vindicate plaintiff's interest in seclusion. This is because the courts should still consider whether defendants used intrusive methods in order to obtain the private information that was published. Tipping $\mathrm{J}$ in Hosking said that the circumstances through which the defendant comes into possession of the information is one method of finding a reasonable expectation of privacy. ${ }^{156}$ So if intrusive methods have been used, then this will assist the plaintiff's claim in the publicity tort. The United Kingdom breach of confidence case, Murray $v$ Big Pictures Ltd, illustrates this approach. The defendant took a photograph of author J.K. Rowling and her husband pushing their infant down a street in a buggy. The nature of the intrusion was relevant to establishing a reasonable expectation of privacy in the photographs. Sir Anthony Clarke MR emphasised that the pictures had been taken deliberately and

154 See, for example, Skoien DCJ's decision in Grosse v Purvis [2003] QDC 151 at [444] where the judge ambitiously created a common law privacy tort to cover all manner of invasions that included the following elements:

(a) willed by the defendant;

(b) which intrudes upon the privacy or seclusion of the plaintiff;

(c) in a manner which could be considered highly offensive to a reasonable person of ordinary sensibilities; and

(d) which causes the plaintiff detriment in the form of psychological or emotional harm or distress which prevents or hinders the plaintiff doing an act which she is lawfully entitled to do.

155 See Stephen Penk and Rosemary Tobin "The New Zealand Tort of Invasion of Privacy: Future directions”, above n 47, at 251-252; and also Daniel Solove “Conceptualising Privacy” (2002) 90 California Law Revue 1087 at 1130.

${ }^{156}$ Hosking v Runting, above n 22, at [249]. 
surreptitiously to be published for a profit and there was no doubt that the parents would have objected to such photos. ${ }^{157}$

If plaintiffs are successful in the publication tort, then the damages awarded should compensate for the harms caused by both the intrusion and the subsequent publication. This recognises that two separate breaches of privacy have occurred.

\section{Conclusion}

Whata J's bold decision in Holland to recognise the intrusion tort as part of New Zealand's common law was a step forward for the protection of individual privacy rights. However, the decision poses more questions than it answers. This essay has discussed how the courts should develop the intrusion tort to balance individual privacy rights against the media's important newsgathering functions. In future, the courts need to give greater consideration to the precise meaning of the words in the tort's formulation so that it can best protect the rights that the tort was designed to vindicate.

${ }^{157}$ Murray v Big Pictures Ltd, above n 93, at [50]. 


\section{Appendices}

A Appendix 1: Broadcasting Standards Authority Privacy Principles Privacy Principle 3

(1) It is inconsistent with an individual's privacy to allow the public disclosure of material obtained by intentionally interfering, in the nature of prying, with that individual's interest in solitude or seclusion. The intrusion must be highly offensive to an objective reasonable person.

(2) In general, an individual's interest in solitude or seclusion does not prohibit recording, filming, or photographing that individual in a public place ('the public place exemption').

(3) The public place exemption does not apply when the individual whose privacy has been allegedly infringed was particularly vulnerable, and where the disclosure is highly offensive to an objective reasonable person.

Privacy Principle 8

Disclosing the matter in the 'public interest', defined as of legitimate concern or interest to the public, is a defence to a privacy complaint.

\section{B Appendix 2: Crimes Act 1961}

\section{G Intimate visual recording defined}

(1) In sections $216 \mathrm{H}$ to $216 \mathrm{~N}$, intimate visual recording means a visual recording (for example, a photograph, videotape, or digital image) that is made in any medium using any device without the knowledge or consent of the person who is the subject of the recording, and the recording is of-

(a) a person who is in a place which, in the circumstances, would reasonably be expected to provide privacy, and that person is-

(i) naked or has his or her genitals, pubic area, buttocks, or female breasts exposed, partially exposed, or clad solely in undergarments; or

(ii) engaged in an intimate sexual activity; or 
(iii) engaged in showering, toileting, or other personal bodily activity that involves dressing or undressing; or

(b) a person's naked or undergarment-clad genitals, pubic area, buttocks, or female breasts which is made-

(i) from beneath or under a person's clothing; or

(ii) through a person's outer clothing in circumstances where it is unreasonable to do so.

(2) In section $216 \mathrm{H}$, intimate visual recording includes an intimate visual recording that is made and transmitted in real time without retention or storage in-

(a) a physical form; or

(b) an electronic form from which the recording is capable of being reproduced with or without the aid of any device or thing.

\section{H Prohibition on making intimate visual recording}

Everyone is liable to imprisonment for a term not exceeding 3 years who intentionally or recklessly makes an intimate visual recording of another person.

\section{Appendix 3: Privacy Act 1993}

\section{Information privacy principles}

The information privacy principles are as follows: $\cdots$

Principle 4

Manner of collection of personal information

Personal information shall not be collected by an agency -

(a) by unlawful means

(b) by means that, in the circumstances of the case, -

(i) are unfair; or

(ii) intrude to an unreasonable extent upon the personal affairs of the individual concerned.

\section{Appendix 4: Restatement (Second) of Torts (1977)}


(1) One who invades the right of privacy of another is subject to liability for the resulting harm to the interests of the other.

(2) The right to privacy is invaded by

(a) Unreasonable intrusion upon the seclusion of another;

(b) appropriation of another person's name or likeness;

(c) unreasonable publicity given to another's private life; and

(d) publicity that unreasonably places he other in a false light before the public.

$\S 652 \mathrm{~B}$

One who intentionally intrudes, physically or otherwise, upon the solitude or seclusion of another or his private affairs or concerns, is subject to liability to the other for invasion of his privacy, if the intrusion would be highly offensive to a reasonable person.

$\S 652 \mathrm{D}$

One who gives publicity to a matter concerning the private life of another is subject to liability to the other for invasion of his privacy, if the matter publicized is of a kind that -

(a) would be highly offensive to a reasonable person, and

(b) is not of legitimate concern to the public. 


\section{Bibliography}

1 Cases

ABC v Lenah Game Meats [2001] HCA 63; (2001) 185 ALR 1.

Aisenson v American Broadcasting Company 220 Cal App 3d 146 (Cal 1990).

Andrews v Televisions New Zealand Ltd [2009] 1 NZLR 220 (HC).

Balfour v TVNZ [2005] NZBSA 129.

Bartnicki v Vopper 532 US 514 (2001).

Baugh v CBS, Inc 838 F Supp 745 (ND Cal, 1993).

BQ\&CR v TVNZ [2002] NZBSA 193, 194, 195, 196.

Bradley v Wingnut Films Ltd [1993] 1 NZLR 415.

Brown v Attorney General [2006] DCR 630; [2006] NZAR 552.

C v Holland [2012] NZHC 2155.

Campbell v Mirror Group Newspapers Ltd [2004] UKHL 22, [2004] 2 AC 457.

Canwest TVWorks Ltd v XY [2008] NZAR 1 (HC).

Case Note 14824 [1997] NZPrivCmr 14.

CD v TV3 Network Services Ltd [2000] NZBSA 141, 142, 143.

CP v TVWorks Ltd [2012] NZBSA 69.

Daily Times Democrat v Graham 276 Ala 380 (1964).

Davies v TVNZ [2005] NZBSA 17.

Dietemann v Time Inc 449 F 2d 245 (9th Cir 1971). 
Doulas v Hello! Ltd (No 3) [2005] EWCA Civ 595; [2006] QB 125.

Evans v Dettlefsen 857 F 2d 330 (6 ${ }^{\text {th }}$ Cir 1988).

Grosse v Purvis [2003] QDC 151.

Haynik v Zimlich 30 Ohio Misc 2d 16 (1986).

Hosking v Runting [2003] 3 NZLR 385 (HC).

Hosking $v$ Runting [2005] 1 NZLR 1 (CA).

Jones v Tsige [2012] ONCA 32.

Machleder v Diaz 538 F Supp 1362 (SDNY, 1982).

Mark v Seattle Times 96 Wash 2d 473 (1981).

Medical Laboratory Management Consultants v American Broadcasting Companies Inc 306 F $3 d 806$ (Ariz, 2002).

Miller v National Broadcasting Company 187 Cal App 3d 1463 (Cal 1987).

Murray v Big Pictures Ltd [2008] EWCA Civ 446, [2009] Ch 481.

O’Connell v TVWorks Ltd [2007] NZBSA 67.

$P \vee D[2000] 2$ NZLR 591 (HC).

Peck v United Kingdom (44647/98) (2003) 36 EHRR 41.

Rawls v Conde Nast Publications, Inc 446 F2d 313 (CA 5 Fla, 1971).

Rogers v Television New Zealand Ltd [2007] NZSC 91, [2008] 2 NZLR 277.

Sanders v ABC 978 F 2d 67 (Cal 1999). 
Shulman v Group W Productions 955 P 2d 469 (Cal 1998).

Television New Zealand Ltd v KW HC Auckland CIV-2007-485-1609, 18

December 2008.

Television New Zealand v Rogers [2007] 1 NZLR 156 (CA).

Tucker v News Media Ownership Ltd [1986] 2 NZLR 716.

TV3 Network Services Ltd v The Broadcasting Standards Authority [1995] 2 NZLR 720.

TVNZ Network Services Ltd v Fahey [1999] 2 NZLR 129.

Wainwright v Home Office [2003] UKHL 53, [2004] 2 AC 406.

\section{$2 \quad$ Statutes and Restatements}

Crimes Act 1961.

Privacy Act 1993.

Restatement (Second) of Torts (1977).

\section{Books, Chapters in Books and Loose Leafs}

John Burrows \& Ursula Cheer (eds) Media Law in New Zealand $\left(6^{\text {th }}\right.$ edition, Wellinton, Lexis Nexis, 2010).

John Edwards \& Paul Roth Privacy law - where are we now? (NZLS CLE, 2013).

Nicole Moreham "Privacy Rights” in Mark Warby QC, Nicole Moreham and Iain Christie (eds) The Law of Privacy and the Media (Second Edition, Oxford University Press, Oxford, 2011) 59.

Nicole Moreham "Why is Privacy Important? Privacy, Dignity and Development of the New Zealand Breach of Privacy Tort” in Jeremy Finn and Stephen Todd (eds) Law, Liberty, Legislation (LexisNexis, 2008) 231. 
Stephen Penk "Common Law Privacy Protection in Other Jursdictions” in Stephen Penk \& Rosemary Tobin (eds) Privacy Law in New Zealand (Brookers, Wellington, 2010) 99.

Stephen Penk “The Privacy Act 1993” in Stephen Penk \& Rosemary Tobin (eds) Privacy Law in New Zealand (Brookers, Wellington, 2010) 49.

Bruce Robertson (ed) Adams on Criminal Law - Offences and Defences (online looseleaf ed, Brookers)

Rosemary Tobin "Media Regulation: The Press Council and The Broadcasting Standards Authority” in Stephen Penk \& Rosemary Tobin (eds) Privacy Law in New Zealand (Brookers, Wellington, 2010) 205.

Stephen Todd The Law of Torts in New Zealand (5 $5^{\text {th }}$ Edition, Wellington, Brookers, 2009).

\section{$4 \quad$ Journal Articles}

William L Prosser “Privacy” (1960) 48(3) California Law Review 383.

Ruth Gavison "Privacy and the Limits of Law” (1980) 89(3) Yale Law Journal 421.

Chris DL Hunt "Conceptualising Privacy and Elucidating its Importance: Foundational Considerations for the Development of Canada's Fledgling Privacy Tort” (2012) 37 Queen’s LJ 167.

Chris DL Hunt "Privacy in the Common Law: A Critical Appraisal of the Ontario Court of Appeal's Decision in Jones v Tsige” (2012) 37 Queens LJ 665.

Lyrissa Barnett Lidsky "Prying, Spying and Lying: Intrusive Nwsgather and What the Law Should Do About It” (1999) 73 Tulane Law Review 173.

Jared A Mackey "Privacy and the Canadian Media: Developing the New Tort of "Intrusion Upon Seclusion" with Charter Values (2012) 2(1) Western Journal of Legal Studies 3. 
N.A. Moreham "Privacy in the Common Law: A Doctrinal and Theoretical Analysis (2005) 121 Law Quarterly Review 628.

N.A. Moreham “Privacy in Public Places” (2006) NZLJ 265.

Dr Nicole Moreham "Private Matters: A Review of the Broadcasting Standards Authority” (NZBSA, 2009).

Stephen Penk \& Rosemary Tobin “The New Zealand Tort of Invasion of Privacy: Future Directions” (2011) 19 Torts Law Journal 191.

Edward L Raymond "Intrusion by News-Gathering Entity as Invasion of Right of Privacy” (1989) ALR 4th 1059.

Daniel Solove “Conceptualising Privacy” (2002) 90 California Law Revue 1087

Samuel Warren and Louis Brandeis "The Right to Privacy” (1890) 4 Harv LR 193.

\section{$5 \quad$ Websites}

Broadcasting Standards Authority "Privacy Principles” <www.bsa.govt.nz>.

Privacy Commissioner "Privacy Act \& Codes: Manner of Collection of Personal Information (Principle 4)” <www.privacy.org.nz>.

\section{Law Commission Reports}

Law Commission Invasion of Privacy: penalties and remedies: review of the law of privacy stage 3 (NZLC r113, 2010)

Law Commission The News Media Meets 'New Media': Rights, Responsibilities and Regulation in a Digital Age (NZLC r 128, 2013).

New South Wales Law Reform Commission Invasion of Privacy (NSWLRC r 120, 2009). 
The text of this paper (excluding the cover page, table of contents, keywords, abstract, footnotes and bibliography) consists of exactly 8,009 words. 